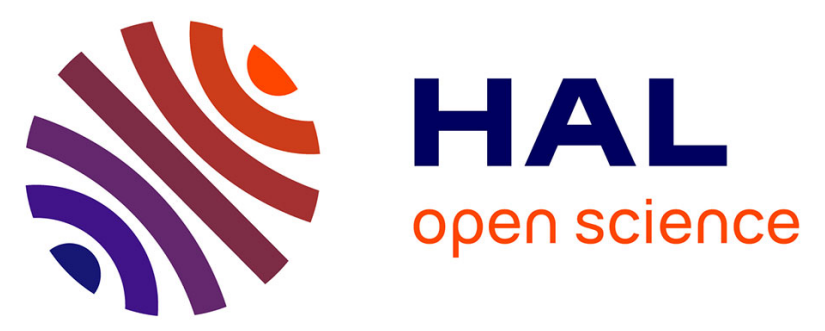

\title{
Variability of carbonaceous aerosols, ozone and radon at Piton Textor, a mountain site on Réunion island (south-western Indian Ocean)
}

Chatrapatty Bhugwant, Emmanuel Riviére, Philippe Keckhut, Jean Leveau

\section{- To cite this version:}

Chatrapatty Bhugwant, Emmanuel Riviére, Philippe Keckhut, Jean Leveau. Variability of carbonaceous aerosols, ozone and radon at Piton Textor, a mountain site on Réunion island (south-western Indian Ocean). Tellus B - Chemical and Physical Meteorology, 2001, 53B (5), pp.546 - 563. 10.3402/tellusb.v53i5.16635 . insu-03580980

\section{HAL Id: insu-03580980 \\ https://hal-insu.archives-ouvertes.fr/insu-03580980}

Submitted on 18 Feb 2022

HAL is a multi-disciplinary open access archive for the deposit and dissemination of scientific research documents, whether they are published or not. The documents may come from teaching and research institutions in France or abroad, or from public or private research centers.
L'archive ouverte pluridisciplinaire HAL, est destinée au dépôt et à la diffusion de documents scientifiques de niveau recherche, publiés ou non, émanant des établissements d'enseignement et de recherche français ou étrangers, des laboratoires publics ou privés.

\section{(c)(1)}

Distributed under a Creative Commons Attribution| 4.0 International License 


\section{Variability of carbonaceous aerosols, ozone and radon at Piton Textor, a mountain site on Réunion island (south-western Indian Ocean)}

Chatrapatty Bhugwant, Emmanuel Riviére, Philippe Keckhut \& Jean Leveau

To cite this article: Chatrapatty Bhugwant, Emmanuel Riviére, Philippe Keckhut \& Jean Leveau (2001) Variability of carbonaceous aerosols, ozone and radon at Piton Textor, a mountain site on Réunion island (south-western Indian Ocean), Tellus B: Chemical and Physical Meteorology, 53:5, 546-563, DOI: 10.3402/tellusb.v53i5.16635

To link to this article: https://doi.org/10.3402/tellusb.v53i5.16635 (c) 2001 The Author(s). Published by Taylor \&
Francis.

曲 Published online: 15 Dec 2016.

Submit your article to this journal 지

山ll Article views: 116

Q View related articles $\sqsubset$ 


\title{
Variability of carbonaceous aerosols, ozone and radon at Piton Textor, a mountain site on Réunion island (south-western Indian Ocean)
}

\author{
By CHATRAPATTY BHUGWANT ${ }^{1 *}$, EMMANUEL RIVIÈRE ${ }^{1}$, PHILIPPE KECKHUT ${ }^{2}$ and \\ JEAN LEVEAU ${ }^{1},{ }^{1}$ Laboratoire de Physique de l'Atmosphe $е$, Université de la La Réunion, 15 Avenue \\ René Cassin - BP 7151, 97715 Saint Denis CEDEX 09, France; ${ }^{2}$ Centre National de la Recherche \\ Scientifique, Service d'Aeronomie; BP 3, 91371 Verrie $\rho$ es-Le-Buisson Cedex, France
}

(Manuscript received 25 October 2000; in final form 2 March 2001)

\begin{abstract}
Black carbon (BC) was monitored during 1997-1999 in the lower troposphere of the southern Indian Ocean at La Réunion island $\left(21.5^{\circ} \mathrm{S}, 55.5^{\circ} \mathrm{E}\right)$. BC concentrations obtained at Piton Textor, an altitude site $(2150 \mathrm{~m})$ representative of free troposphere, exhibited diurnal patterns and concentrations different from urban locations on the island, with maximum concentrations observed at daytime $\left(\sim 50-150 \mathrm{ng} / \mathrm{m}^{3}\right)$ and minimum levels $\left(\sim 10-70 \mathrm{ng} / \mathrm{m}^{3}\right)$ at night-time. BC diurnal variation is anti-correlated with diurnal ozone measured semi-continuously in parallel during 1998-1999, suggesting possible interaction of ozone and precursors $\left(\mathrm{NO}_{x}\right.$, VOC, etc.) on carbonaceous aerosols, especially at night-time. Daytime BC enhancement may be explained by dynamical processes, due to updraught of air masses from lower levels to the troposphere, while at night-time, this process is reversed. Daytime ozone depletion is governed by photochemical processes, due to low precursor levels, while night-time ozone recovery is mainly driven by dynamical processes from upper tropospheric layers. Night-time BC and ozone in the lower troposphere show a marked seasonal pattern too, with minimum levels during austral summer ( $\left.\sim 15 \mathrm{ng} / \mathrm{m}^{3}, 22 \mathrm{ppbv}\right)$, secondary peaks in autumn and spring $\left(\sim 35 \mathrm{ng} / \mathrm{m}^{3}, 36 \mathrm{ppbv}\right)$ and maximum values during austral winter $\left(\sim 70 \mathrm{ng} / \mathrm{m}^{3}, 41 \mathrm{ppbv}\right)$ respectively. Night-time BC and ozone seasonalities are concordant with night-time radon seasonal trend in the lower troposphere, indicating that sampled air masses have mainly a marine origin in summer, off the African biomass burning season, and a continental origin in austral winter and spring. Winter and spring BC and ozone enhancement corroborate with fire-count maximum peaks observed over Africa and Madagascar, suggesting that the main cause is combustion products long-range transported in stable layers evidenced by thermodynamic analysis using 1996-1999 PTU soundings. These assessments are confirmed by 5-day backtrajectories, which show important seasonal shift in origin of air masses arriving in the lower troposphere of the south-western Indian Ocean.
\end{abstract}

\section{Introduction}

Black carbon or soot is primarily produced by all types of combustion (Wolff and Klimisch, 1982; Cachier, 1998). This aerosol has noticeable optical

\footnotetext{
* Corresponding author. e-mail : bhugwant@univ-reunion.fr
}

(absorption, scattering, etc.) properties and may generate atmospheric heating effect, while decreasing the surface temperature (Penner et al., 1993; Penner, 1995; Cooke et al., 1999). The main sink of this aerosol is wet and dry deposition (Charlson and Ogren, 1982; Ruellan and Cachier, 2001). From laboratory and field experiments, it has been shown that $\mathrm{BC}$ may also oxidise atmospheric 
constituents such as sulphur compounds via catalytic processes and thus influence atmospheric chemistry (Chang et al., 1981; Finlayson-Pitts and Pitts, 1999).

Ozone is a green-house gas and as such, it has a long lifetime in the atmosphere (Crutzen and Andreae, 1990; Thompson et al., 1996). Because of its chemical characteristics, ozone may interact with other atmospheric species and play an important rôle in the chemistry of the troposphere (Kalberer et al., 1996; Crutzen et Lawrence, 1997; Hauglustaine et al., 1999). From case-studies and long-term ozone measurements carried out in the south-western Indian Ocean, it has been assessed that the main causes leading to upper tropospheric ozone variability are dynamical and photochemical processes (Baldy et al., 1996; Diab et al., 1996; Randriambelo et al., 1999), with, however, focus on winter season. The main tropospheric ozone sources are stratosphere-troposphere (ST hereafter) exchanges and biomass burning inputs (Thompson et al., 1997; Bhugwant et al., 1998; Baray et al., 1999), while the main sinks are thought to be cloud processes and storms/cyclones (SC hereafter), which occur at different seasons of the year (Brémaud and Taupin, 1998; Baray et al., 1998; Roumeau et al., 2000).

Biomass burning occurs during austral winter and spring and is mostly situated in the intertropical zone (Levine, 1991, 1995, 1996). Pollutants (aerosols and trace gases) emitted during combustion processes may be found far from source regions either as primary or as secondary products (Andreae et al., 1984; Fulberg et al., 1999). Previous studies based on statistical data (demography, land use, global vegetation) carried out, show predominance of Africa in global biomass burning emissions in southern hemisphere estimations (Hao and Liu, 1994; Hao et al., 1996).

It has also been shown in some measurement (satellite, ozone, etc.) and modelling studies (Goldammer et al., 1996; Krishnamurti et al., 1996; Olson, 1996, 1999; Taupin et al., 1999) that an eastwards transport of fire pollutants occurs regularly during austral winter (see also JGR, 1996: TRACE-A and SAFARI experiments).

As discussed earlier, the influence of several processes (SC, ST exchanges, biomass burning, convection, etc.) upon tropospheric ozone budget sustains the difficulty of assessing quantitatively ozone variability over the south-western Indian
Ocean (Taupin et al., 1999; Randriambelo et al., 2000). Firstly, this is due to lack of conjugate measurement of other atmospheric $\left(\mathrm{NO}_{x}, \mathrm{BC}\right.$, etc. $)$ data. Most importantly, little is known about diurnal variation of atmospheric constituents in the lower troposphere, due to complex characteristics (orography, meteorology, etc.) of La Réunion island, while some studies undertaken at similar locations in the northern hemisphere are available (Atlas et al., 1996; Hauglustaine et al., 1997). Indeed, previous works undertaken in the troposphere at La Réunion island used twice-monthly ozone sounding profiles, which may certainly cause misinterpretation of some processes such as SC, ST exchanges, etc., which are punctual phenomena. Secondly, in most works, only case-study trajectories were shown and considered as seasonal trends to explain the origin of air masses (Baldy et al., 1996; Randriambelo et al., 2000). Up to now, no thorough thermodynamic and simultaneous kinematic analysis had been undertaken to determine transport pattern of atmospheric constituents at different seasons at La Réunion island.

In this sense, the present work extends stable layer analysis to the study region. Cluster backtrajectories arriving at different seasons in the troposphere over the south-western Indian Ocean are also analysed. We describe lower tropospheric aerosols and ozone characteristics, i.e., their diurnal and seasonal trends observed at Piton Textor, a mountain site situated in the lower troposphere of La Réunion island. With the help of radon, a tracer of continental air masses (Hansen et al., 1990), we confirm the origin and main causes of $\mathrm{BC}$ aerosols and ozone variability. We then draw conclusions about the influence of source/sink processes and transport pattern on atmospheric ( $\mathrm{BC}$ and ozone) variability in the lower troposphere of the south-western Indian Ocean.

\section{Description of data sets and instruments}

\subsection{Location}

This study took place at La Réunion Island $\left(21^{\circ} \mathrm{S} ; 55.5^{\circ} \mathrm{E}\right)$, a small island situated at 2000 and $800 \mathrm{~km}$ east of South Africa and Madagascar respectively, as shown in Fig. 1a. At La Réunion island, highest altitude $3100 \mathrm{~m}$ above sea level (asl hereafter), and following the relief of the island, 

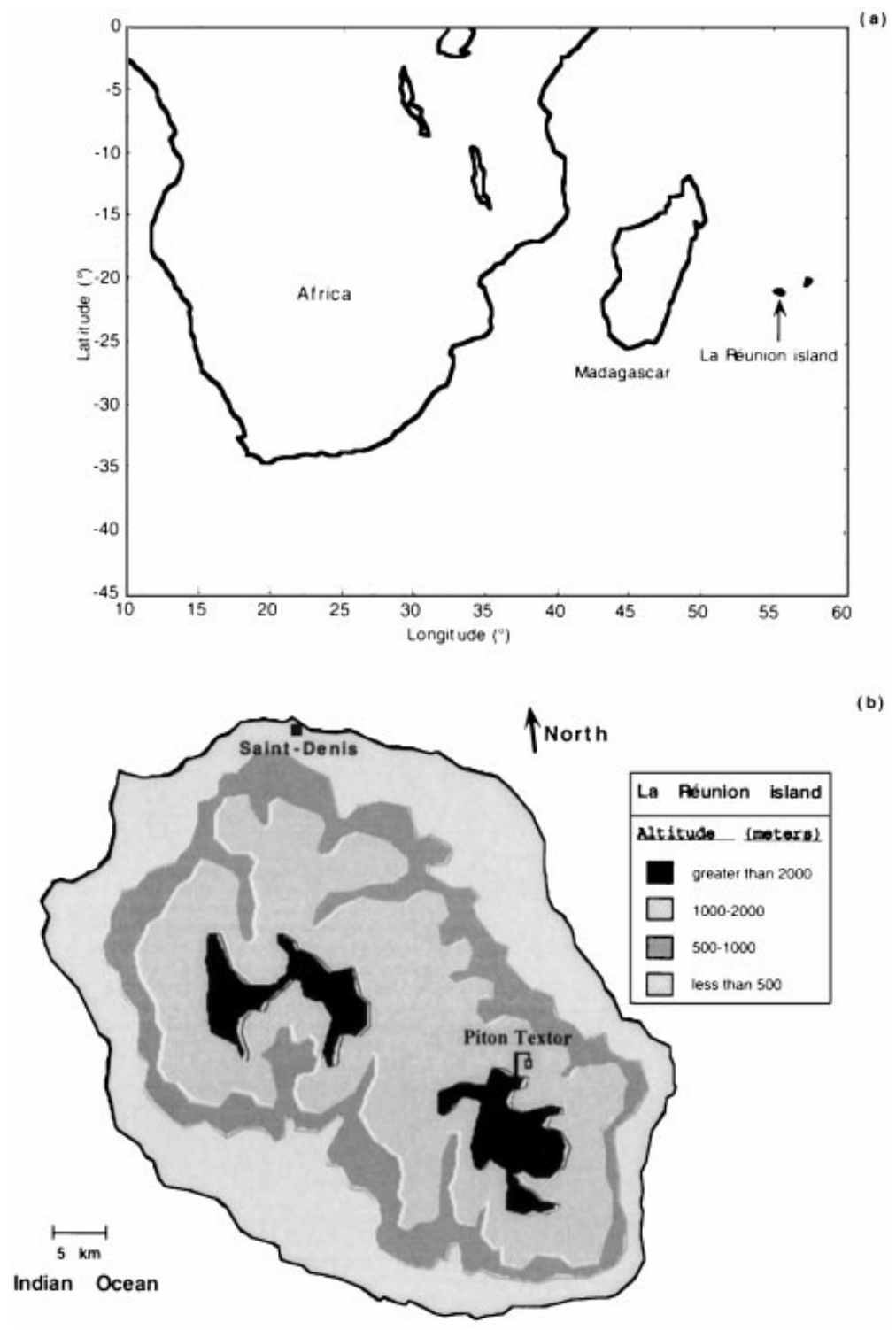

(b)

Fig. 1. (a) Geographical context of the southern Indian Ocean and (b) position of Piton Textor, the experimental location at La Réunion island.

an altitude site Piton Textor $(2150 \mathrm{~m}$ asl) was selected for our experiments (Fig. 1b). Agricultural activities are low in the area of the site and the latter is situated in an uninhabited region, in the middle of the island. Piton Textor BC measurements are also compared with Amsterdam island data, a remote oceanic location (southern Indian Ocean). Meteorological data collected at Saint-
Denis (Fig. 1b), a semi-urban site, were analysed in order to examine meteorological conditions encountered in the area.

\subsection{Data description}

The experimental sites dedicated for the experiments, the instruments operated and the period of 
each measurement are summarised in Table 1. Black carbon aerosol is used as an inert particulate tracer of combustion, and thus for our sampling site, as a tracer of anthropogenic inputs (Hansen et al., 1990; Bhugwant and Brémaud, 2001a).

BC was monitored with an AE-14 Aethalometer (Magee Scientific) from March 1997 to June 1999 at Piton Textor, with a time-resolution of $30 \mathrm{~min}$ between each measurement. The Aethalometer draws ambient air at a flow rate of approximately 18 litres/min through a surface area of $1 \mathrm{~cm}^{2}$ of a quartz fiber tape. The accumulation of black carbon aerosols during the time-base period on the filter causes a light attenuation, which is converted into a $\mathrm{BC}$ mass concentration using the standard calibration factor of 19 and following Beer's law (Liousse et al., 1993; Ruellan and Cachier, 2001). The sensitivity of the instrument is enhanced by multi-reflection of light through the fibrous quartz matrix and by measurements of incremented attenuation. BC data were subsequently averaged to a time-resolution of $1 \mathrm{~h}$ in order to be compared with other measurements (ozone and radon).

Atmospheric soundings have been performed twice-monthly since 1996 at Saint-Denis airport. Ozone concentration profiles were deduced from a standard electrochemical ECC (ElectroChemical Cell) sonde which measures vertical ozone partial pressure. The principle of measurement of the ECC sonde is based on a redox reaction, where ambient ozone is pumped and analysed. Temperature, relative humidity, pressure, and ozone $\left(\mathrm{PTU}-\mathrm{O}_{3}\right)$ profiles measured from surface up to the lower troposphere $(0$ to $30 \mathrm{~km}$ high) are obtained from a Vaisala RS- 80 case equipped with integrated sensors (Taupin et al., 1999).

The uncertainty of ozone measurements obtained by the sonde was previously found to be $10 \%$ in the troposphere (Barnes et al., 1985). In a recent intercomparison study, ozone concentrations obtained using a Dasibi photometer and ECC sonde, respectively, in the marine boundary layer (MBL hereafter), showed uncertainties of $\sim 9 \%$ between the 2 instruments (Bhugwant et al., 2000b; Bhugwant et al., 2001a). 101 soundings covering 3 years data (January 1996 to December 1999), and encompassing Piton Textor atmospheric data measurements, were analysed in this study, with, however, some gaps in the database due to lack of measurements.

Radon-222 ( $\mathrm{Rn}$, hereafter) is a noble gas produced in the ${ }^{238} \mathrm{U}$ decay series by emissions from soils of most land masses. Its concentration over the ocean is negligible in comparison with the land source strength (Polian et al., 1986). Rn is a natural radioactive gas with a half-life of about 3.8 days and is seldom used as a tracer of air masses having a continental origin (Hansen et al., 1990; Cachier et al., 1996). Its concentration has been measured by a radon counter (Klein, 1990) since July 1997 at Piton Textor. This instrument pumps air to be analysed at a flow rate of 1 litre/min; the time base between each measurement is $30 \mathrm{~min}$.

Meteorological data including wind intensity, temperature and rainfall have been collected on an hourly basis from semi-automatic sensors by Météo-France since 1996 at Saint-Denis. These data were used to reinforce BC and ozone analysis.

The origin and direction of sampled air masses

Table 1. Sampling location, instruments operated and measurements obtained from 1996 to 1999

\begin{tabular}{|c|c|c|c|c|c|}
\hline Location & Site & Instrument & Measurements & Start date & End date \\
\hline \multirow[t]{3}{*}{ La Réunion Island } & Saint-Denis & $\begin{array}{c}\text { ozone } \\
\text { soundings }\end{array}$ & $\begin{array}{c}\text { Profiles of temperature, } \\
\text { humidity, ozone and } \\
\text { potential temperature }\end{array}$ & January 1996 & August 1999 \\
\hline & & $\begin{array}{c}\text { meteorological } \\
\text { data }\end{array}$ & $\begin{array}{c}\text { temperature, } \\
\text { wind (speed, direction), } \\
\text { rainfall }\end{array}$ & January 1996 & December 1999 \\
\hline & Piton Textor & $\begin{array}{l}\text { Aethalometer } \\
\text { Dasibi } \\
\text { radon counter }\end{array}$ & $\begin{array}{c}\text { BC } \\
\text { ozone } \\
\text { Radon-222 }\end{array}$ & $\begin{array}{c}\text { March } 1997 \\
\text { October } 1998 \\
\text { July } 1997\end{array}$ & $\begin{array}{c}\text { April } 1999 \\
\text { October } 1999 \\
\text { April } 1998\end{array}$ \\
\hline
\end{tabular}

Tellus 53B (2001), 5 
arriving in the troposphere were also investigated using 5-day isentropic trajectories using the European TM2Z model, following the Ramonet et al. (1996) and Baldy et al. (1996) methods. Backtrajectory calculations presented in this work are obtained from the ECMWF $\left(1^{\circ}\right.$ grid, 15 levels of pressure between 1000 and $10 \mathrm{hPa}$, 6-h time resolution) database. From air mass trajectories calculated over 3 years, (1996 to 1998), some general patterns of the vertical and horizontal circulation of air masses arriving over La Réunion island have been evidenced.

\section{Meteorological conditions at La Réunion island}

Most previous atmospheric studies undertaken over the south-western Indian Ocean region discussed briefly the general pattern of meteorological conditions prevailing there (Baldy et al., 1996; Baray et al., 1998). It is known that thermodynamic parameters such as solar radiation, humidity, winds, etc., may affect trace constituents (e.g., ozone, $\mathrm{NO}_{x}$, etc.) concentrations and variability (Finlayson-Pitts and Pitts, 1987). In this sense, we tried to gain information on the general pattern of some meteorological parameters and look for possible links with atmospheric variability, in the southern tropics. Fig. 2 presents monthly mean temperature, wind speeds (Fig. 2a) and rainfall (Fig. 2b) obtained from January 1997 to December 1999 (averaged to a typical year) at Saint-Denis.

In austral summer, there is highest insolation and humidity (Baray et al., 1999) in the southern tropics (mean temperature, rainfall and wind speeds are $\sim 26.5^{\circ} \mathrm{C}, 120 \mathrm{~mm}$ and $5.5 \mathrm{~m} / \mathrm{s}$ respectively). During the season, SC are frequent and easterlies/westerlies are weakened. These conditions contribute to highest rainfall and cloud cover, which may in turn have well-known physico-chemical implications (photolysis rates, microphysical processes, etc.) upon atmospheric species (Crutzen, 1995; Finlayson-Pitts and Pitts, 1999). Conversely, in austral winter, when convective and SC processes are low or nonexistent, easterlies/westerlies are strengthened (highest wind speeds), while rainfall are lowest $\left(\sim 21.5^{\circ} \mathrm{C}\right.$, $50 \mathrm{~mm}$ and $6.7 \mathrm{~m} / \mathrm{s}$ respectively).

The contrasted seasonality of meteorology influence the displacement of Inter Tropical
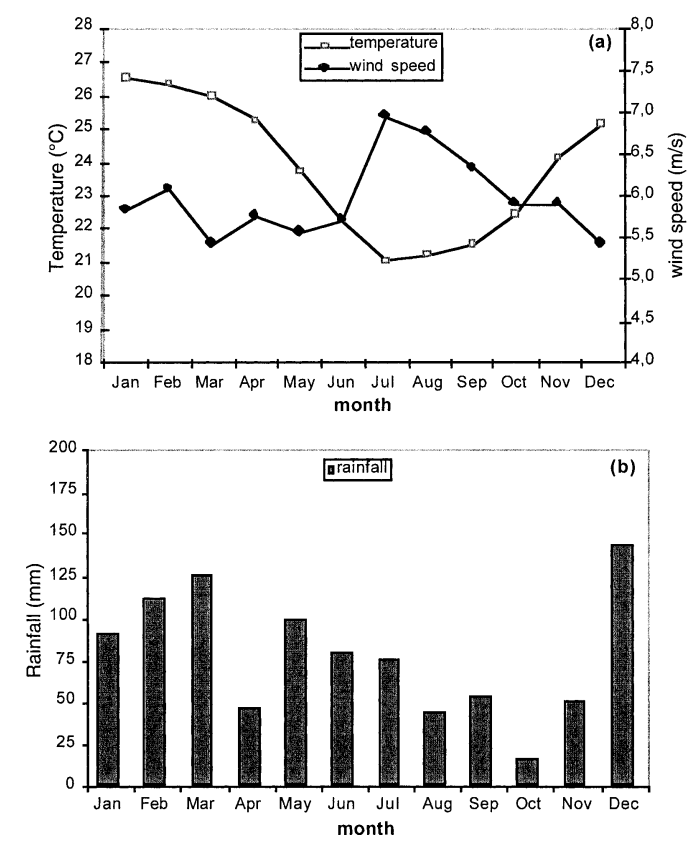

Fig. 2. Monthly mean temperature and wind speed (a) and integrated rainfall (b) obtained at Saint-Denis from 1997-1999 meteorological data.

Convergence Zone (ITCZ hereafter), which is at its extreme equatorward position in summer and extreme poleward position in winter (Hastenrath, 1991). However, dynamical processes exhibit important spatial and temporal (e.g., origin of air mass trajectories, intensity of winds, etc.) variability, too, from one season to another over the south-western Indian Ocean (Bhugwant et al., 2001a). As such, the latter process may also in part contribute to atmospheric variability. Finally, the seasonality of parameters such as rainfall, insolation, humidity, etc., may influence concentrations and chemistry of atmospheric constituents (aerosols and trace gases), in the southern tropics, as discussed herein.

\section{Stability of the atmosphere and transport pattern over the south-western Indian Ocean}

Up to now, few thorough (spatial and temporal) transport patterns of atmospheric tracers have been undertaken in the troposphere of the southern Indian Ocean, with, however, some case-study trajectory analysis conducted in some works 
(Baldy et al., 1996; Randriambelo et al., 1999; Miller et al., 1999). Other studies based on trajectory analysis undertaken over the African continent showed that air parcels injected into the troposphere are subject to horizontal transport in stable layers from Africa towards adjacent oceans (Garstang et al., 1996; Tyson et al., 1996, 1998). In this sense, we firstly tried to establish the existence of stable structures over the southern Indian Ocean, from preliminary thermodynamic and kinematic analysis, extended to La Réunion island.

\subsection{Spatial and temporal distribution of stable layers}

The subsidence inversion associated with dynamical and photochemical processes on atmo-

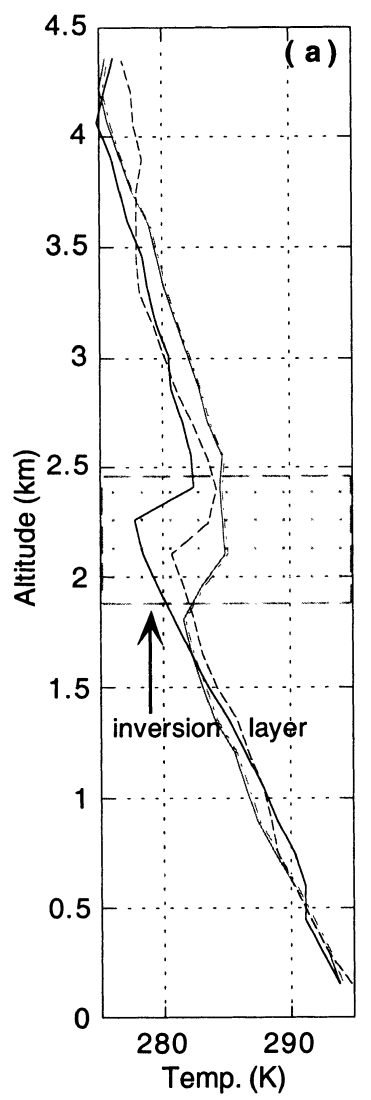

spheric species is thought to be caused by the sinking motion of air masses (Stull, 1988; Hastenrath, 1991). This leads to compression and heating of the air below, resulting in a change in the lapse rate or formation of an inversion layer (Finalyson-Pitts and Pitts, 1999). In the present work, stable structures are firstly determined using threshold values of simultaneous lapse rate changes of temperature, virtual potential temperature $\left(\theta_{\mathrm{e}}\right)$, relative humidity $(\mathrm{RH})$, and ozone $(\Delta \theta e / \mathrm{d} z \sim 5 \mathrm{~K} / \mathrm{km} ; \Delta T / \mathrm{d} z \sim 5 \mathrm{~K} / \mathrm{km}$, etc.) obtained from January 1996 to December 1999 PTU-O ${ }_{3}$ soundings (Finlayson-Pitts and Pitts, 1987).

Fig. 3 presents typical day-and-night vertical temperature (a), $\theta_{\mathrm{e}}$ (b), $\mathrm{RH}$ (c) and ozone (d) profiles obtained during early austral winter (29/07/98 at 5.45 p.m. (dashed line), 30/07/98 at
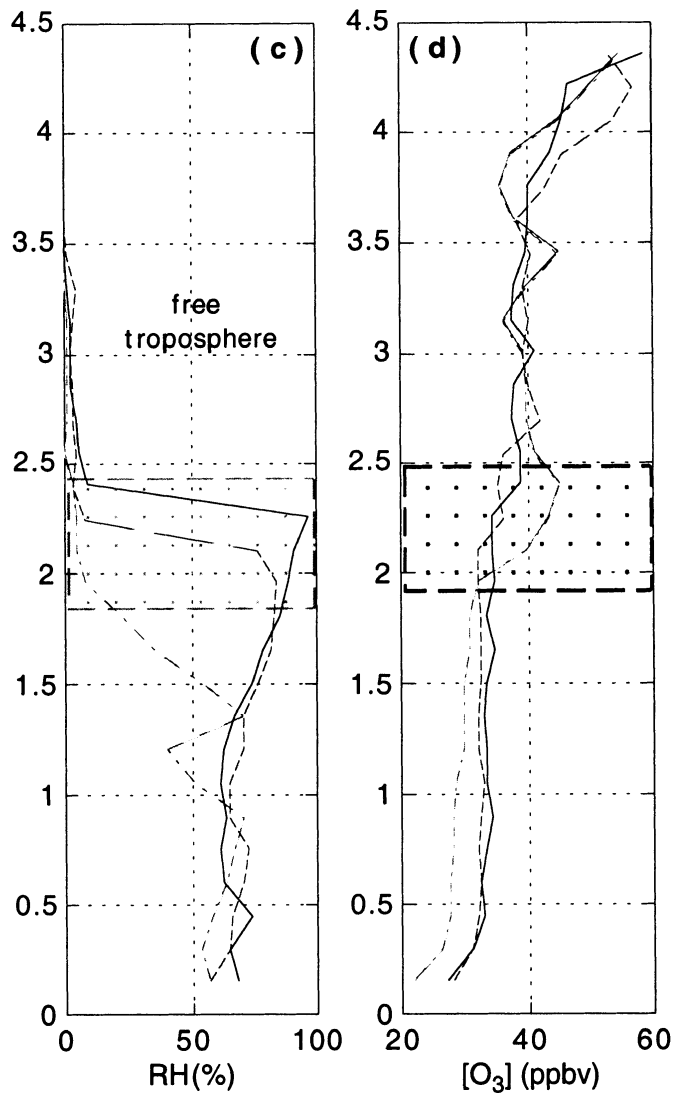

Fig. 3. Day-to-night temperature (a), virtual potential temperature gradient (b), humidity (c) and ozone (d) concentration profiles obtained by PTU-O 3 soundings in the evening (5.45 p.m.) of 29/07/98 (dash-dot line), morning (11.50 a.m.) of 30/07/98 (dashed line) and morning (10.30 a.m.) of 31/07/98 (solid line) respectively.

Tellus 53B (2001), 5 
11.50 a.m. (dash-dot line) and 31/07/98 at 10.30 a.m. (solid line) respectively) at Saint-Denis airport. From temperature profiles (Fig. 3a), we notice that the first thermal inversion or stable structure, corresponding to important lapse-rate change, appears in the $1.8-2.45 \mathrm{~km}$ altitude-band. This altitude-band is called the inversion layer, and the free troposphere is found above it.

The base of the inversion structure caps the MBL, and the thermal inversion layer often coincides with the upper limit of easterly winds prominent in the southern Indian Ocean (Hastenrath, 1991). Correspondingly, we observe an important lapse-rate change on $\theta_{\mathrm{e}}$ profiles (Fig. $3 \mathrm{~b}$ ) at this altitude-band. Important differences in humidity $(\Delta \mathrm{RH} \sim 60-80 \%)$ below and above the inversion layer (Fig. 3c) are also noticed, suggesting that air masses in the lower troposphere have a different origin and characteristics to those arriving in the MBL. A comparison of ozone profiles (Fig. 3d) on both sides of the structure, in the MBL and the free troposphere, show important differences in concentration levels and point out that the inversion layer may prevent efficient vertical mixing of air masses due to stability of the atmosphere. A close look at thermodynamic (temperature, $\theta_{\mathrm{e}}, \mathrm{RH}$, etc.) parameters obtained within a 24-to-36 $\mathrm{h}$ interval points out that that the altitude level of the inversion layer is subject to little diurnal variation $(\Delta z \sim \pm 0.6 \mathrm{~km})$. Importantly, it may be noticed that the inversion layer altitude is lowest during night-time, in the absence of both convective and SC processes during the season. At daytime, however, the inversion layer altitude is higher due to convection combined with upslope-downslope motion of air masses partly caused by important relief of the island.

Thermodynamic analysis confirms that Piton Textor is most often situated in the lower troposphere during night-time. It has notably previously been shown that the thermal inversion layer above the MBL is subject to important seasonal variation (Bhugwant et al., 2000a), while presently it is found to exhibit little day-to-night variation. The seasonality of the thermal inversion layer altitude is thought to be due to large-scale subsidence, coupled with dynamical processes such as intensity of prevailing easterlies, position of the ITCZ, etc.

Stable-layer analysis using thermodynamic parameters is consistent with previous studies undertaken in neighbouring regions, over east African coasts (Garstang et al., 1996). It also asserts the existence of an inversion structure at comparable latitudes and altitude over southwestern Indian Ocean (Hastenrath, 1991; Tyson et al., 1998).

\subsection{Regional transport: trajectory analysis}

We determined the origin of air masses arriving over the south-western Indian Ocean prior to atmospheric measurements by calculating 5-day backtrajectories at 15 pressure levels (MBL to upper troposphere) from 1996 to 1998. Due to similarity in trajectory origin and annual trends in the troposphere, only trajectories arriving at $600 \mathrm{hPa}$ pressure level (4.5 km altitude), being statistically representative of transport in the lower troposphere, are chosen in the present study for discussion. From 15-days cluster trajectories (2/day) calculated during 1998, 4 typical periods (March, May, September and November) representative of austral summer, autumn, winter and spring respectively, are presented in Fig. 4.

During summer (Fig. 4a), it may be seen that air masses arriving in the lower troposphere over La Réunion island are mainly subject to the southwesterly air regime. Furthermore, austral summer corresponds to a tropical depression period in Southern Hemisphere (M. France, personal communication, 2000) and might explain northeasterly origin of some trajectories.

In autumn (Fig. 4b), we notice an important shift in origin and direction of air masses (westerly), as compared to summer trajectories, most of which originate from east Africa and Madagascar, before attaining the south-western Indian Ocean. Inter-annual changes in horizontal transport pathways (not shown) are also observed in autumn, which could be explained by seasonality of westerlies, movement of ITCZ, convective and dynamical processes, etc.

In winter (September, Fig. 4c), most air parcels originate from south and east Africa and north of Madagascar before attaining La Réunion island. It may be seen that more than $80 \%$ of trajectories follow westerlies and are long-range transported from Africa into preferential layers.

In spring (November, Fig. 4d), most air masses exhibit a repetitive south-westerly direction. These trajectories originate from south-east Africa and 

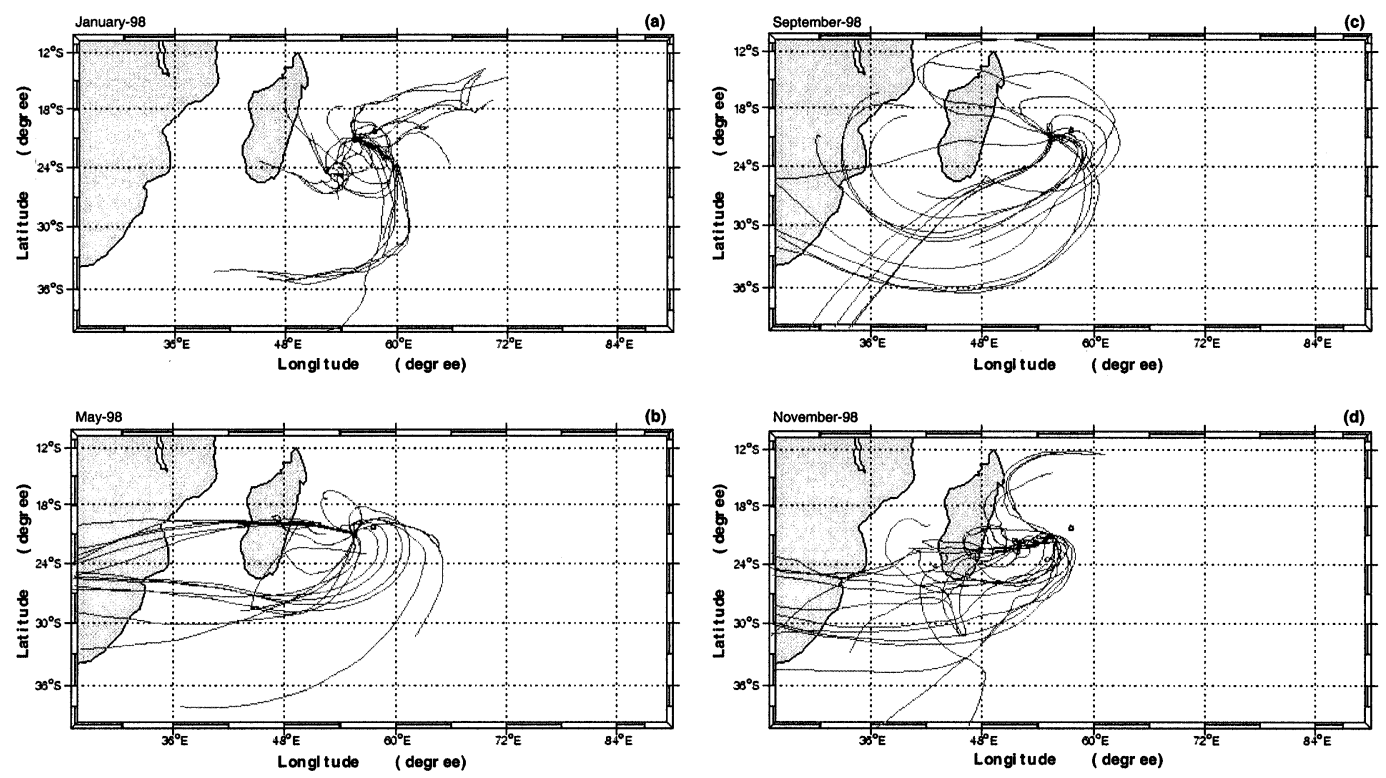

Fig. 4. Mid-level 5-day backtrajectories $(\sim 4.5 \mathrm{~km})$ calculated from ECMWF data showing flow transition with northerly, westerly and southerly origins following the season. Trajectories calculated for January (a), May (b), September (c) and November (d) 1998, respectively, in south-western Indian Ocean.

transit over the south of Madagascar before arriving at La Réunion island.

Finally, from trajectory analysis, we notice an important seasonal shift in the origin of air masses (marine/continental) attaining the troposphere over the south-western Indian Ocean.

\section{Variability of BC aerosols, ozone and radon in the lower troposphere}

\subsection{Diurnal variation of black carbon at Piton Textor}

Following the geographic configuration of the island, Piton Textor (2150 m asl) was selected for monitoring atmospheric data representative of the free troposphere in the southern oceanic region, as discussed earlier (Bhugwant et al., 2000a). BC being a tracer of anthropogenic inputs has been used to characterise the variability of combustion effluents at the site. Fig. 5 represents mean diurnal $\mathrm{BC}$ concentration variation measured at different seasons (summer (a), autumn (b), winter (c) and spring (d)), from March 1997 to June 1999, at Piton Textor. We most importantly notice that the BC diurnal variation at this altitude site exhibits trends and levels different to those observed at semi-urban/urban, oceanic and continental locations (Allen et al., 1999; Ruellan and Cachier, 2001). Indeed, in densely inhabited areas, 2 peaks corresponding to morning and evening rush hours are observed on BC concentration profiles. Daytime $\mathrm{BC}$ values are found to be at moderate levels and night-time $\mathrm{BC}$ concentrations exhibit minimum levels, when traffic circulation is at moderate levels (Bhugwant et al., 2000a). Nighttime $\mathrm{BC}$ trend is explained by dynamical processes via downward transport of air masses from the troposphere towards the MBL, as pointed out in previous works (Ayers et al., 1997; Brémaud et al., 1998), and the inverse process occurs during daytime. This is due to the important relief of the island, which contributes to daily upslopedownslope motion of air masses.

Piton Textor BC concentration profiles exhibits a repetitive pattern throughout the year, with, however, important differences in levels and amplitude, from one season to another. BC diurnal variation is atypical of trends generally observed in already published works. It may be recalled that up to now, data presented in literature have mostly been carried out at remote oceanic or 

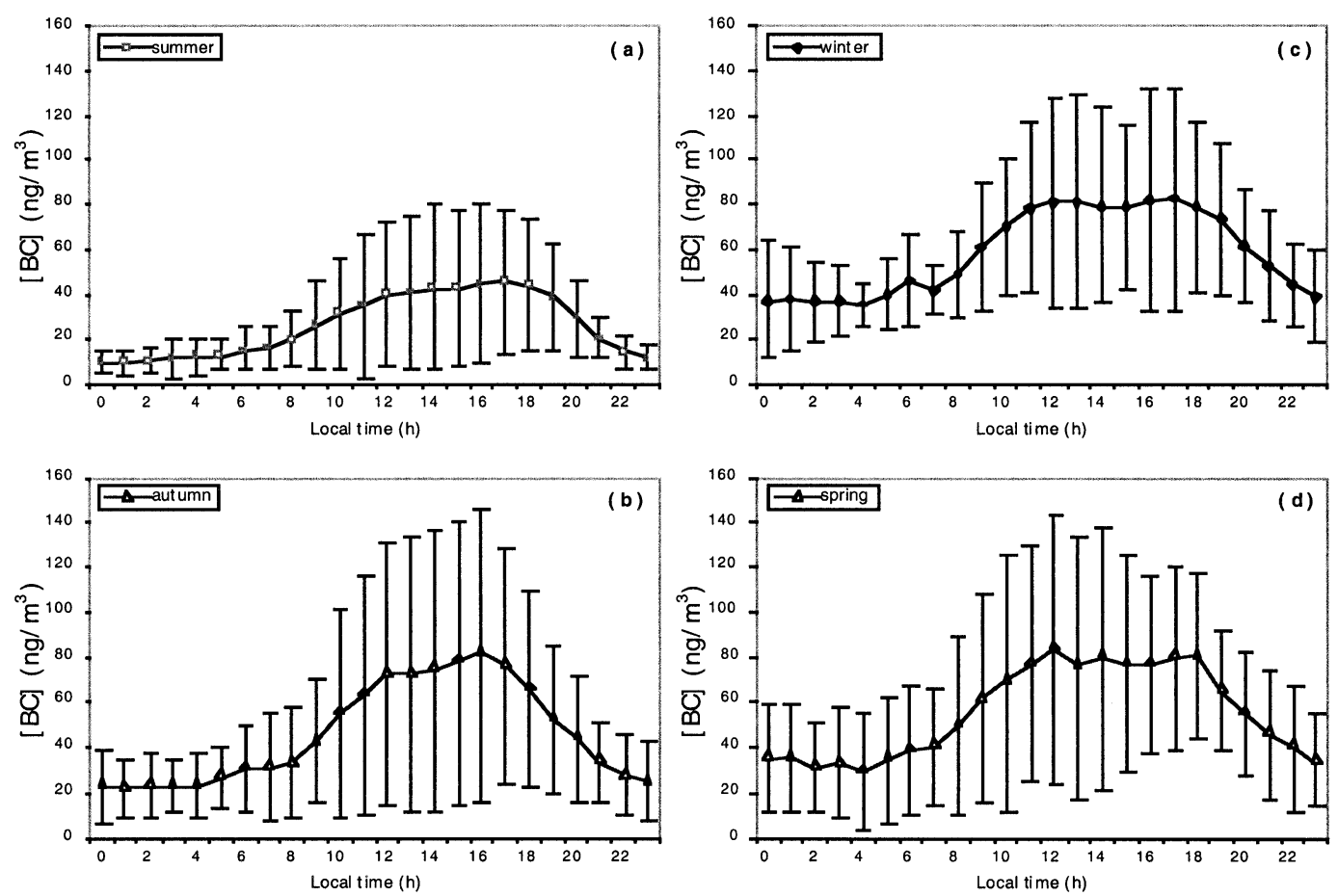

Fig. 5. Mean diurnal BC concentration variation measured at different seasons (summer (a), autumn (b), winter (c) and spring (d)) from March 1997 to June 1999 at Piton Textor.

urban continental regions (Allen et al., 1999; Ruellan and Cachier, 2001), while tropospheric $\mathrm{BC}$ aerosols measurements are scarce in the southern tropics.

We clearly notice that $\mathrm{BC}$ concentrations exhibit minimum values in summer $\left(\sim 25 \mathrm{ng} / \mathrm{m}^{3}\right)$, moderate levels in autumn $\left(\sim 45 \mathrm{ng} / \mathrm{m}^{3}\right)$ and maximum values in winter and spring $\left(\sim 55 \mathrm{ng} / \mathrm{m}^{3}\right)$. Interestingly, Piton Textor $\mathrm{BC}$ levels are quite low, as compared to semi-urban locations on the island (Bhugwant et al., 2000a) (see also Table 3). $\mathrm{BC}$ values are comparable in order of magnitude with other remote locations (Cachier et al., 1996; Bhugwant et al., 2001b), suggesting the quite unpolluted nature of the site. BC seasonal variation observed at Piton Textor may be due to local but also regional anthropogenic inputs in the lower troposphere. Indeed, due to the important relief of the island, most of the population resides on the coasts. As explained earlier, localscale processes such as daily upslope-downslope motion of air masses may transport pollutants produced downwind, from inhabited regions to the site, thus explaining higher daytime $\mathrm{BC}$ levels. A close look at night-time $\mathrm{BC}$ data points out important seasonal variation too, with minimum levels observed in summer, moderate levels in autumn, and maximum levels in winter and spring. It may be emphasized that during night-time, local anthropogenic activities are kept at minimum levels at La Réunion island.

It may thus be assumed that night-time BC concentrations reflect regional-scale atmospheric variability of the lower troposphere, via a conjunction of several processes such as long-range transport (see Subsection 4.2), gravimetry, large-scale subsidence of the atmosphere, etc., when convection is low and air masses are subject to downward motion.

\subsection{BC seasonal variation in the lower troposphere}

From continuously-recorded data, measurements were filtered from 10.00 p.m. to 7.00 a.m. (night-time period) in order to ensure data representative of the free troposphere, by minimis- 
ing local contamination (Bodhaine et al., 1995). Monthly mean night-time BC concentration variation obtained at Piton Textor from March 1997 to April 1999 and averaged over a typical year is presented in Fig. 6.

For the sake of comparison with $\mathrm{BC}$ variability in the MBL close to the study-region, we also reported in the figure reanalysed, monthly mean BC data obtained by Cachier et al. (1996) from 1991 to 1993 at Amsterdam island. At Piton Textor, 4 distinct periods for $\mathrm{BC}$ variation are evidenced with a pronounced inter-annual pattern. Indeed, we notice a first period corresponding to austral summer (January-March), where low $\mathrm{BC}$ values are observed, varying in the range $8-15 \mathrm{ng} / \mathrm{m}^{3}$. During the season, there is intense rainfall in tropical regions (Fig. 2b), which may also contribute to aerosol concentration decrease via scavenging processes (Ogren et al., 1984). From trajectory analysis (see Subsection 4.2), we have seen that during summer, air masses have mostly an oceanic origin. Night-time BC concentrations measured in summer at Piton Textor are thus representative of background levels of the free troposphere of the region. Low inter-annual summer BC levels vary in a fairly wide range and could be due to meteorology (winds, rainfall, etc.), which exhibits important variability during this period of the year (Hastenrath, 1991). Indeed, SC events occurring regularly during the season each year may also in part explain lowest atmospheric levels, via deposition (scavenging) processes (Baray et al., 1999; Bhugwant et al., 2001b).

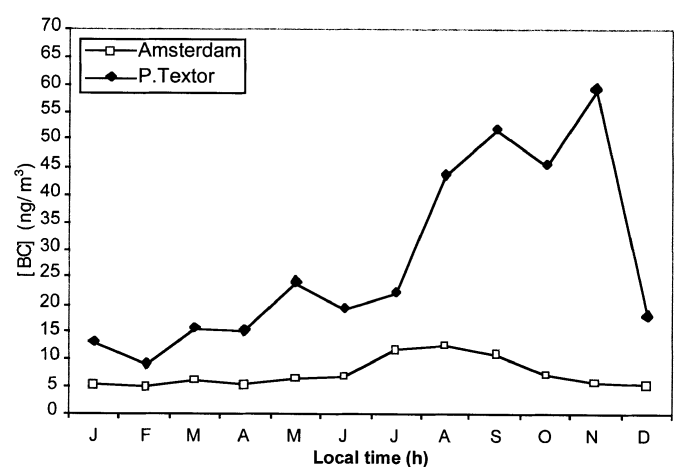

Fig. 6. Monthly mean BC concentrations obtained from 1997 to 1999 at Piton Textor (- - line, night-time data) and from 1991 to 1993 at Amsterdam island $(-\square-$ line) (Cachier et al., 1996).
In autumn (April to June), night-time BC concentrations exhibit a secondary peak $\left(\sim 30 \mathrm{ng} / \mathrm{m}^{3}\right)$. Night-time BC enhancement suggests that the region may be contaminated by primary bush fires occurring in the south and east Africa (Cachier et al., 1996; Andreae et al., 1998). These assessments are consistent with previous satellite studies (Koffi et al., 1996; Cooke et al., 1996) which show that primary fires occur each year in south and east Africa in autumn. As confirmed by trajectory analysis (Subsection 4.2), long-range transport of combustion aerosols from Africa towards the Indian Ocean might explain BC secondary peaks observed during the season. However, these observations had not been stressed and/or discussed in previous works carried out at La Réunion island.

Night-time BC concentrations show highest peaks in austral winter (August to October), corresponding to an increase by a factor of at least 5 , as compared to summer BC levels. Winter BC enhancement is mainly due to transport of biomass burning products from Africa and Madagascar (see Subsection 4.2), when convective processes are intense in the lower and middle troposphere (Diab et al., 1996; Thompson et al., 1996, 1997; Levine et al., 1996).

High injection of smoke and plumes during intense savanna fires may explain the preferential altitude of transport pathways (see Subsection 4.1), up to areas extending to the south-western Indian Ocean region (Stocks and Kauffman, 1997; Talbot et al., 1999).

In spring (October-December), night-time $\mathrm{BC}$ are at moderate levels, when burnt surfaces show a decrease over Africa, while in Madagascar, fires are still important, suggesting that the troposphere of our regions is mostly concerned with a closer source, with, however, less burning surfaces than in Africa (Olson et al., 1999; Randriambelo et al., 2000). These assessments are confirmed by a shift in transport pattern, as described in Subsection 4.2.

$\mathrm{BC}$ concentration variability at Amsterdam island is comparable in pattern with Piton Textor BC measurements, with, however, notable differences levels and in trends during late winter and spring. Indeed, BC concentrations at Amsterdam island show a decrease during winter and spring, while at Piton Textor, higher levels are present. Discrepancy in BC levels between the 2 sites may be due to differences in transport processes. This may also in part be due to the closeness of our

Tellus 53B (2001), 5 
location with source regions (Africa, Madagascar), as compared to Amsterdam island, a more remote southern-eastern oceanic location.

\subsection{Ozone diurnal and seasonal variation in the lower troposphere}

We also investigated ozone diurnal variation in the lower troposphere in order to sort out the influence of source (primary and secondary emissions) and sink (meteorology, etc.) processes upon the ozone variability. It may be recalled here that up to now, ozone diurnal variation studies have mostly been dedicated to MBL in the southern Indian Ocean or over other oceans (Johnson et al., 1990, 1993; Brémaud et al., 1998; De Laat et al., 1999). Furthermore, most of these studies were based upon campaigns only (Brémaud and Taupin, 1998; Naja et al., 1999), which could not explain the implication of various processes associated with ozone diurnal variation throughout the year, in the southern tropics, a complex region in terms of both radiative and ozone budget.
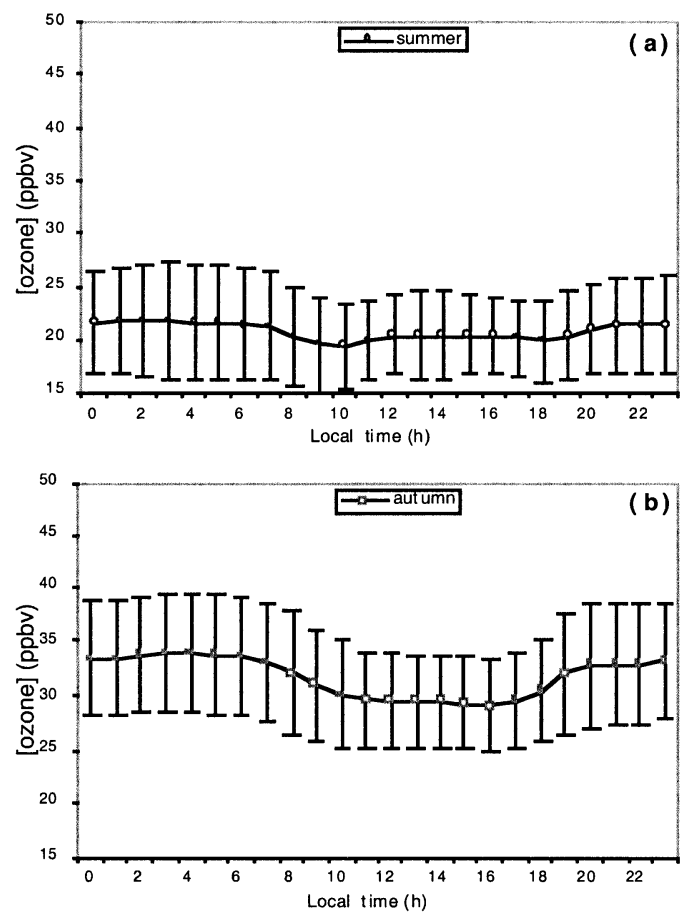

Moreover, diurnal variation studies on mountain sites are scarce in the southern tropics (Bhugwant et al., 1998), while some studies at similar sites exist in the northern hemisphere (Atlas et al., 1996; Hauglustaine et al., 1997, 1999).

Fig. 7 presents mean diurnal ozone concentration variation obtained at different seasons (summer (a), autumn (b), winter (c) and spring (d)), from October 1998 to October 1999 at Piton Textor. We first notice that ozone diurnal variation exhibits different trends and patterns to those observed at remote (Rhoads et al., 1997; De Laat et al., 1999) and semi-urban/urban, continental and/or oceanic locations (Bhugwant et al., 2000b; Finlayson and Pitts, 1999). Indeed, we notice important daytime ozone loss $(\sim 20-36 \mathrm{ppbv})$, when photochemical processes prevail. Ozone depletion occurs early in the morning and stops at sunset, with a minimum at noon. At night-time, however, important ozone recovery $(\sim 22-40 \mathrm{ppbv})$ is mainly driven by dynamical processes. This diurnal pattern is repetitive at all seasons, with, however, important differences in

Fig. 7. Mean diurnal ozone concentration variation measured at different seasons (summer (a), autumn (b), winter (c) and spring (d)) from October 1998 to October 1999 at Piton Textor. 
day-to-night amplitude and levels. Mean ozone concentration also exhibits important seasonal variation, with minimum levels in summer ( $\sim 22$ ppbv; photochemical depletion), maximum levels in winter ( $\sim 38 \mathrm{ppbv}$; biomass burning) and moderate levels in autumn and spring $(\sim 34 \mathrm{ppbv}$; ST exchanges and biomass burning), as for BC variability. Ozone seasonal trend is concordant with previous works carried out with ozone soundings at La Réunion island (Baldy et al., 1996; Taupin et al., 1999).

Finally, we notice that both primary (BC) and secondary (ozone) pollutants exhibit the same seasonal variation. Results suggest that main causes leading to $\mathrm{BC}$ and ozone variability in the lower troposphere at La Réunion island are seasonal shift of air sample origin (oceanic-toanthropogenic, i.e., sink-to-source), superimposed on prevailing photochemical processes, whose influence is dependent upon seasonality of meteorology.

\subsection{Correlation between $B C$ and ozone: ozone $/$ BC ratio}

We tried to gain more information about links (origin of sources) between BC and ozone diurnal variation at different seasons. In this sense, we calculated the regression slope of $\mathrm{BC}$ with ozone (Table 2). Important correlation between $\mathrm{BC}$ and ozone is observed at all seasons $\left(R^{2} \sim 0.8-0.9\right)$, with, however, noticeable differences in the regression slope coefficients, from one season to another. The $\mathrm{BC} / \mathrm{O}_{3}$ ratio was also calculated in order to quantify the evolution of $\mathrm{BC}$ with respect to that of ozone at different seasons.

The lowest $\mathrm{BC} / \mathrm{O}_{3}$ ratio is observed during summer, when tropospheric air samples have a marine origin, SC conditions prevail, there is no biomass burning, and rainfall is maximum, in the south-western Indian Ocean. In autumn, the mod- erate $\mathrm{BC} / \mathrm{O}_{3}$ ratio may be tied to primary vegetation fires occurring over Africa. ST processes occurring regularly during the season may also in part contribute to lower tropospheric ozone increase (Baray et al., 1998; Randriambelo et al., 1999). The moderate winter $\mathrm{BC} / \mathrm{O}_{3}$ ratio points out that there is efficient en-route ozone photochemical production during long-range transport of contaminants from east Africa and Madagascar. This is consistent with maximum BC peaks and air parcel trajectory path observed during the season, when scavenging processes are low. In spring, however, two main causes may explain lower tropospheric ozone enhancement (highest $\mathrm{BC} / \mathrm{O}_{3}$ ratio) over the south-western Indian Ocean, as compared to winter. Firstly, as discussed earlier, biomass burning is less intense over Madagascar than Africa during the season. Secondly, rapid transport from Madagascar, a closer source, may not allow substantial ozone production. Results again confirm our previous assessments about the seasonal shift in the origin of air samples (mainly biomass burning pollutants in winter and spring) and their transport pathways. Finally, we clearly observe a 3 -mode structure, with minimum $\mathrm{BC} / \mathrm{O}_{3}$ ratio in summer $(\sim 1.25)$, moderate values in autumn and winter $(\sim 1.45)$ and a maximum in spring $(\sim 1.8)$.

\subsection{Atmospheric tracer of continental origin}

In order to distinguish between continental (anthropogenic) and oceanic air masses, we investigated the origin of sampled air masses from preliminary continuous radon-222 measurements obtained by a radon counter (Klein, 1990) at Piton Textor.

Mean seasonal Rn measured during night-time (10.00 p.m.-7.00 a.m.) from July 1997 to April 1998 is presented in Fig. 8. Mean seasonal night-time $\mathrm{BC}$ concentrations have also been presented in

Table 2. Regression slopes and correlation coefficient of $\mathrm{BC}$ and ozone and $\mathrm{BC} / \mathrm{O}_{3}$ ratio calculated at different seasons at Piton Textor

\begin{tabular}{lcc}
\hline Season & \multicolumn{1}{c}{ Regression slopes } & $\left.[\mathrm{BC}] / \mathrm{O}_{3}\right]$ ratio \\
\hline summer & {$[\mathrm{BC}]=-0.04 \cdot\left[\mathrm{O}_{3}\right]+22 ; R^{2}=0.82$} & 1.25 \\
autumn & {$[\mathrm{BC}]=-0.08 \cdot\left[\mathrm{O}_{3}\right]+36 ; R^{2}=0.92$} & 1.42 \\
winter & {$[\mathrm{BC}]=-0.09 \cdot\left[\mathrm{O}_{3}\right]+44 ; R^{2}=0.84$} & 1.50 \\
spring & {$[\mathrm{BC}]=-0.19 \cdot\left[\mathrm{O}_{3}\right]+46 ; R^{2}=0.88$} & 1.78 \\
\hline
\end{tabular}

Tellus 53B (2001), 5 


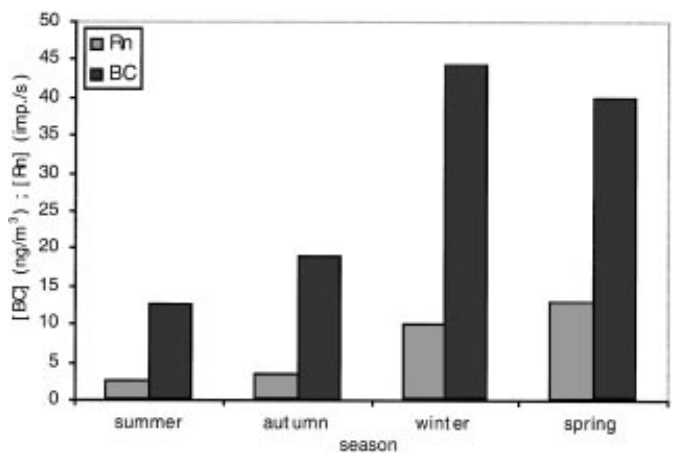

Fig. 8. Mean seasonal night-time $\mathrm{BC}$ and radon variation obtained from July 1997 to April 1998 at Piton Textor.

the figure in order to be compared with radon variability. Rn concentrations show low levels in austral summer ( $\sim 2.5 \mathrm{Imp} . / \mathrm{s})$ and confirm that air masses arriving in the lower troposphere at Piton Textor have mainly an oceanic origin.

In winter, radon values increase by a factor of at least $4(\sim 10 \mathrm{Imp} . / \mathrm{s})$ and point out that Piton Textor air samples have mainly a continental origin in the season. These assessments are also corroborated with $\mathrm{BC}$ and ozone variability and confirm the regional origin of combustion pollutants in air parcels measured at Piton Textor during winter.

However, a careful look at both $\mathrm{BC}$ and $\mathrm{Rn}$ data sets points out some differences in levels and amplitude following the season, which may be explained by differences in origin and transit time of air masses. BC-Rn discrepancy is especially noticeable in spring, during which time it may be assessed that air masses are mostly emitted from Madagascar a closer but less intense continental (and pollutant) source than Africa. Furthermore, air parcels arriving in the troposphere may be subject to anticyclonic conditions and thus have a longer residence time in upper layers before subsiding (Garstang et al., 1996). These processes may in turn have important influence upon tropospheric aerosols and trace gas variability.

Finally, combined measurements of different atmospheric tracers $\mathrm{BC}$ and $\mathrm{Rn}$ indicate different regimes of air masses sampled at Piton Textor. It may be presumed that several factors such as source effect (origin and strength), dynamics (transport) and convective processes, etc., concur to carbonaceous aerosols seasonal variation in the lower troposphere of south-western Indian Ocean, as confirmed by ozone and radon variability.

We also compared our results with campaigns and/or long-term measurement studies undertaken over the south-western Indian Ocean region and some other regions. Results are summarized in Table 3. From the data sets, we observe that Piton Textor night-time $\mathrm{BC}$ seasonal trend and pattern is similar to that observed at Amsterdam island, with, however, important differences in amplitude and levels. Semi-continuous ozone measurements are consistent in order of magnitude with recent observations in the Indian Ocean (De Laat et al., 1999; Zachariasse et al., 2000). The ozone seasonal trend is also in accord with twice-monthly ozone soundings presented in previous works (Baldy et al., 1996; Randriambelo et al., 2000).

\section{Summary and conclusions}

We characterised $\mathrm{BC}$ aerosols and ozone diurnal and seasonal variation in the lower troposphere over the south-western Indian Ocean during the 1997-1999 period. Radon was also measured in parallel with $\mathrm{BC}$ and ozone at Piton Textor, an altitude site of La Réunion island. To gain information about meteorology and dynamics, we also studied some meteorological parameters, in conjunction with thermodynamic and trajectory analysis. From thermodynamic analysis, it has been shown that Piton Textor is regularly situated in the lower troposphere, as also pointed out in previous studies (Bhugwant et al., 2000a). Kinematic analysis from 5-day backtrajectories calculated for 15 consecutive days at different seasons show an important seasonal shift in the origin of air masses attaining the lower troposphere at La Réunion island. Indeed, during summer, most air masses have marine (south-west and north-east) origin. In autumn, most of them have an easterly direction originating from east Africa. In winter, most trajectories originate from south Africa and Madagascar before attaining La Réunion island. In spring, most air masses originate from south-east Africa and again transit over the south of Madagascar before arriving at La Réunion island. Thermodynamic and kinematic analyses presented here, and which are extended to the study-region, are consistent with previous 
Table 3. Comparison of mean BC and ozone concentrations obtained at different locations in the MBL and free troposphere at La Réunion with those obtained in some regions of southern Indian Ocean close to La Réunion island

\begin{tabular}{|c|c|c|c|c|}
\hline Location & Season & {$[\mathrm{BC}]\left(\mathrm{ng} / \mathrm{m}^{3}\right)$} & Ozone (ppbv) & Author \\
\hline Amsterdam Island & $\begin{array}{c}\text { summer } \\
\text { autumn } \\
\text { winter } \\
\text { spring }\end{array}$ & $\begin{array}{c}5 \\
6 \\
11 \\
8\end{array}$ & $\begin{array}{l}16.8 \\
30.6 \\
27.5 \\
21.5\end{array}$ & $\begin{array}{l}\text { Cachier et al. (1996) } \\
\text { Gros et al. (1998) }\end{array}$ \\
\hline $\begin{array}{l}\text { Piton Textor } \\
\text { (night-time) }\end{array}$ & $\begin{array}{c}\text { summer } \\
\text { autumn } \\
\text { winter } \\
\text { spring }\end{array}$ & $\begin{array}{l}12 \\
25 \\
41 \\
32\end{array}$ & $\begin{array}{l}22.5 \\
32.2 \\
40.1 \\
36.4\end{array}$ & This work \\
\hline Sainte-Rose & $\begin{array}{c}\text { summer } \\
\text { autumn } \\
\text { winter } \\
\text { spring }\end{array}$ & $\begin{array}{c}11 \\
14.5 \\
24 \\
20\end{array}$ & $\begin{array}{l}15.5 \\
25.5 \\
22.6\end{array}$ & Bhugwant et al. (2001b) \\
\hline Saint-Denis & $\begin{array}{l}\text { autumn } \\
\text { winter }\end{array}$ & $\begin{array}{l}550 \\
360\end{array}$ & $\begin{array}{l}25.5 \\
24.6\end{array}$ & $\begin{array}{c}\text { Bhugwant et al. (2000b) } \\
\text { Brémaud et al. (1998) }\end{array}$ \\
\hline $\begin{array}{l}\text { Cape Grim } \\
\text { (MBL) }\end{array}$ & $\begin{array}{l}\text { summer } \\
\text { autumn } \\
\text { winter } \\
\text { spring }\end{array}$ & & $\begin{array}{l}16 \\
29 \\
31 \\
23\end{array}$ & Ayers et al. (1996) \\
\hline $\begin{array}{c}\text { Cape Grim } \\
\text { (free troposphere) }\end{array}$ & $\begin{array}{c}\text { summer } \\
\text { autumn } \\
\text { winter } \\
\text { spring }\end{array}$ & & $\begin{array}{l}23 \\
31 \\
36 \\
30\end{array}$ & Ayers et al. (1996) \\
\hline $\begin{array}{l}\text { Southern Indian Ocean } \\
\qquad(\mathrm{MBL})\end{array}$ & autumn & & $\begin{array}{c}11-17 \\
11-17 \\
18\end{array}$ & $\begin{array}{c}\text { Rhoads et al. (1997) } \\
\text { De Laat et al. (1999) } \\
\text { Zachariasse et al. (2000) }\end{array}$ \\
\hline $\begin{array}{l}\text { Southern Indian Ocean } \\
\text { (free troposphere) }\end{array}$ & autumn & & $\begin{array}{l}25-30 \\
30-40\end{array}$ & $\begin{array}{c}\text { De Laat et al. (1999) } \\
\text { Zachariasse et al. (2000) }\end{array}$ \\
\hline
\end{tabular}

stable-layer observations carried out at comparable altitudes and latitudes over Africa and adjacent oceans, using trajectory analysis (Garstang et al., 1996; Tyson et al., 1998).

$\mathrm{BC}$ diurnal variation exhibits a repetitive pattern throughout the year, with maximum levels at daytime and minimum levels at night-time. BC diurnal variation describes distinct trends and patterns compared to those observed in remote (Table 3) and semi-urban/urban continental environments (Allen et al., 1999; Ruellan and Cachier, 2001; Bhugwant et al., 2000a). However, important differences in day-to-night amplitude and levels are observed from one season to another. Nighttime BC exhibits important seasonal trend too, with lowest levels in summer $\left(\sim 10 \mathrm{ng} / \mathrm{m}^{3}\right)$ during regular $\mathrm{SC}$ events and maximum rainfall, second- ary peaks in autumn and spring $\left(\sim 35 \mathrm{ng} / \mathrm{m}^{3}\right)$ and maximum peaks in winter $\left(\sim 70 \mathrm{ng} / \mathrm{m}^{3}\right)$.

Ozone concentration measured in parallel with BC from October 1998 to October 1999 at Piton Textor shows different diurnal patterns and trends compared to those observed at remote oceanic (Table 3) and semi-urban locations (Rhoads et al., 1997; De Laat et al., 1999; Brémaud et al., 1998; Bhugwant et al., 2000b). Indeed at Piton Textor, a net daytime ozone loss is observed while at night-time, there is important ozone recovery.

Day-time ozone loss, beginning at sunrise and ending at sunset, is mainly due to photochemical processes in the presence of quite low amounts of precursors at the site (Finlayson and Pitts, 1999). At night-time, however, it may be presumed that prevailing dynamical processes contribute to 
ozone recovery via vertical-and-horizontal transport of air masses. Ozone diurnal variation is anticorrelated with $\mathrm{BC}$ and exhibits repetitive patterns throughout the year, with, however, important differences in day-to-night amplitude and levels, following the season. Night-time ozone exhibits the same seasonal trend as $\mathrm{BC}$, with minimum concentration measured in summer and maximum levels in winter.

We compared Piton Textor BC and ozone measurements with campaigns and/or long-term measurement studies undertaken over the south-western Indian Ocean region. Results are summarized in Table 3. From the Table 3 data sets, we observe that Piton Textor night-time BC seasonal trend and pattern is similar to that observed at Amsterdam island, with, however, important differences in amplitude and levels. Semi-continuous ozone measurements are consistent, in order of magnitude, with recent observations in the Indian Ocean (De Laat et al., 1999; Zachariasse et al., 2000). The ozone seasonal trend is also in accord with twice-monthly ozone soundings presented in previous works (Baldy et al., 1996; Randriambelo et al., 2000).

Night-time radon measurements also show a similar seasonal trend as $\mathrm{BC}$ and ozone in the lower troposphere, pointing out the marine-tocontinental nature of sampled air from summer to winter, as also shown by trajectory analysis. Indeed, in summer and autumn, night-time radon exhibits low levels, indicating that most air masses have a marine origin. This season also corresponds to absence of bush fires, as shown by satellite observations over source regions (Africa and Madagascar) (Cooke et al., 1996; Olson et al.,
1999; Randriambelo et al., 2000). Maximum radon levels observed in winter and spring confirm that air masses attaining Piton Textor have mainly a continental origin.

Finally, we show that BC exhibits 4 periods of variation in the lower troposphere of the southwestern Indian Ocean. Seasonal variations of combustion aerosols are mainly linked to dynamical processes, source strength (burnt surfaces) over Africa and Madagascar and shift in origin of air masses (burnt regions, transport, etc.), as confirmed by trajectory analysis.

This work should be considered as a preliminary step in characterisation of tropospheric BC aerosol variability in a tropical region. This certainly deserves further investigation in order to assess the chemical and radiative impact of combustion products on a regional scale. The atmospheric data presented here may be helpful to compare with recent INDOEX experiments undertaken over the southern Indian Ocean.

\section{Acknowledgements}

The authors gratefully acknowledge Professor J. Leveau and Dr. M. Bessafi for helpful discussions and comments. We are also indebted to Dr. M. Ramonet and P. Bousquet for trajectory analysis. We also thank J.-M. Metzger and T. Mara for technical support. Météo France is acknowledged for providing meteorological data. We importantly acknowledge the two anonymous reviewers who provided numerous constructive and relevant suggestions highlighting different aspects of the paper.

\section{REFERENCES}

Allen, G. A., Lawrence, J. and Koutrakis, P. 1999. Field validation of a semi-continuous method for aerosol black carbon (aethalometer) and temporal patterns of summertime hourly black carbon measurements in southwestern PA. Atmos. Environ. 33, 817-823.

Andreae, M. O., Andreae, T. W., Ferek, R. J. and Raemdonck, H. 1984. Long range transport of soot carbon in the marine atmosphere. Sci. Tot. Environ. 36, 73-80.

Andreae, M. O., Andreae, T. W., Annegarn, H., Beer, J., Cachier, H., le Canut, P., Elbert, W., Maenhaut, W. Salama, I., Wienhold, F. G. and Zenker, T. 1998. Airborne studies of aerosol emissions from savanna fires in South Africa: 2. Aerosol chemical composition. J. Geophys. Res. 103, D24, 32,119-32,128.
Atlas, E. L. and Ridley, B. A. 1996. The Mauna Loa Observatory Photochemistry Experiment: Introduction. J. Geophys. Res. 101, D9, 14,531-14,541.

Ayers, G. P., Granek, H. and Boers, R. 1997. Ozone in the marine boundary layer at Cape Grim: model simulation. J. Atmos. Chem. 27, 179-195.

Baldy, S., Ancellet, G., Bessafi, M., Badr, A. and Lan Sun Luk, D. 1996. Field observations of the vertical distribution of tropospheric ozone at the island of La Réunion (southern tropics). J. Geophys. Res. 101, 23,835-23,849.

Barnes, R. A., Bandy, A. R. and Torres, A. L. 1985. Electrochemical concentration cell ozonesonde accuracy and precision. J. Geophys. Res. 90, 7881-7887. 
Baray, J.-L., Ancellet, G., Taupin, F., Bessafi, M., Baldy, S. and Keckhut, P. 1998. Subtropical tropopause break as a possible stratospheric source of ozone in the tropical troposphere. J. Atmos. Sol. Terr. Phys. 60, 27-36.

Baray, J.-L., Ancellet, G., Randriambelo, T. and Baldy, S 1999. Tropical cyclone Marlene and stratosphere-troposphere exchange. J. Geophys. Res. 104, $13,953-13,970$.

Bhugwant, C., Riviepe, E., Cachier, H., Posny, F. and Leveau, J. 1998. Seasonal variation of tropospheric aerosols by ground based measurements at La Réunion island $\left(20.8^{\circ} \mathrm{S}, 55.5^{\circ} \mathrm{E}\right) .1998$ IEEE International Geoscience and Remote Sensing Symposium Proceedings. Igarss'98 2, 731-733.

Bhugwant, C., Cachier, H., Bessafi, M. and Leveau, J. 2000a. Impact of traffic on black carbon aerosol concentration at La Réunion island (Southern Indian Ocean). Atmos. Environ. 34, 3464-3473.

Bhugwant, C., Cachier, H., Brémaud, P., Roumeau, S. and Leveau, J. 2000b. Chemical effect of carbonaceous aerosols on the diurnal cycle of MBL ozone at a tropical site: measurements and simulations. Tellus 52B, 1232-1248.

Bhugwant, C. and Brémaud, P. 2001a. Simultaneous measurements of black carbon, $\mathrm{PM}_{10}$, ozone and $\mathrm{NO}_{x}$ variability at a locally polluted island in the southern tropics. J. Atmos. Chem., in press.

Bhugwant, C., Bessafi, M., Riviepe, E. and Leveau, J. 2001b. Diurnal and seasonal variation of carbonaceous aerosols at a remote $\mathrm{MBL}$ site of La Réunion island. Atmos. Res. 57, 105-121.

Bodhaine, B. A. 1995. Aerosol absorption measurements at Barrow, Mauna Loa, and the south pole. J. Geophys. Res. 100, 8967-8975.

Brémaud, P. J., Taupin, F., Thompson, A. M. and Chaumerliac, N. 1998. Ozone nighttime recovery in the marine boundary layer: measurement and simulation at Reunion Island. J. Geophys. Res. 103, 3463-3473.

Brémaud, P. J. and Taupin, T. 1998. Cloud influence on ozone diurnal cycle in the marine boundary layer at Réunion island. Atmos. Res. 47-48, 285-298.

Cachier, H., Liousse, C., Pertuisot, M.-H., Gaudichet, A. Echalar, F. and Lacaux, J.-P. 1996. African fire particulate emissions and atmospheric influence, biomass burning and global change, ed. E. J. S. Levine. London, England, MIT Press, 1, 428-440.

Cachier, H. 1998. Carbonaceous combustion particles. Atmospheric particles. Wiley, New York, eds. R. M Harrison and R. E. Van Grieken, 5, 295-349.

Chang, S. G., Toossi, R. T. and Novakov, T. 1981. The importance of soot particles and nitrous acid in oxidizing $\mathrm{SO}_{2}$ in atmospheric aqueous droplets. Atmos. Environ. 15, 1287-1292.

Charlson, R. J. and Ogren, J. A. 1982. The atmospheric cycle of elemental carbon, particulate carbon: atmospheric life cycle, eds. G. T. Wolff and R. L. Klimisch: Life cycle. Plenum Press, pp. 6-16.

Cooke, W. F., Koffi, B. and Grégoire, J.-M. 1996. Season- ality of vegetation fires in Africa from remote sensing data and application to a global chemistry model. J. Geophys. Res. 101, 15, 21,051-21,065.

Cooke, W. F., Liousse, C., Cachier, H. and Fechter, F. 1999. Construction of a $1^{\circ} \times 1^{\circ}$ fossil fuel emission dataset for carbonaceous aerosol and implementation and radiative impact in the ECHAM-4 model. J. Geophys. Res. 104, D18, 22,137-22,162.

Crutzen, J. P. and Andreae, M. O. 1990. Biomass burning in the tropics: impact on atmospheric chemistry and biogeochemical cycles. Science 250, 1669-1678.

Crutzen, P. J. 1995. Ozone in the troposphere. In: Composition, chemistry and climate of the atmosphere, ed. H. B. Singh. Van Nostrand Reinhold, New York, ch. 10.

Crutzen, P. J. and Lawrence, M. 1997. Ozone clouds over the Atlantic. Nature 388, 625-626.

De Laat, A. T. J., Zachariasse, M., Roelofs, G. J., Van Velthoven, P., Dickerson, R. R., Rhoads, K. P., Oltmans, S. J. and Leliveld, J. 1999. Tropospheric $\mathrm{O}_{3}$ distribution over the Indian Ocean during spring 1995 evaluated with a chemistry-climate model. J. Geophys. Res. 104, D11, 13,881-13,893.

Diab, R., Thompson, A. M., Zunckel, M., Coetzee, G. J. R., Combrink, J., Bodeker, G. E., Fishman, J., Sokolic, F., McNamara, D. P., Archer, C. B. and Nganga, D. 1996. Vertical ozone distribution over southern Africa and adjacent oceans during SAFARI-92. J. Geophys. Res. 101, 23,823-23,833.

Finlayson-Pitts, B. J. and Pitts Jr., J. N. 1987. Atmospheric chemistry: fundamentals and experimental techniques, ed. B. John. Wiley \& Sons, Wiley-Interscience Pub., New York.

Finlayson-Pitts, B. and Pitts Jr., J. N. 1999. Chemistry of the upper and lower atmosphere, theory, experiments and applications, eds. B. Finlayson-Pitts and J. N. Pitts Jr. Academic Press.

Fulberg, H., Newell, R. E., Longmore, S. P., Zhu, Y., Westberg, D. J., Browell, E. V., Blake, D. R., Gregory, G. L. and Sachse, G. W. 1999. A meteorological overview of the Pacific explanatory Mission (PEM) Tropics period. J. Geophys. Res. 101, 5585-5623.

Garstang, M., Tyson, P. D., Swap, R., Edwards, M. Källberg, P. and Lindesay, J. A. 1996. Horizontal and vertical transport of air over southern Africa. J. Geophys. Res. 101, 23,721-23,736.

Goldammer, J. G., Pfund, J. L., Helfert, M. L., Lula, K. P. and STS-61 Mission crew 1996. Use of the earth observation system in the space shuttle program for research and documentation of global vegetation fires: a case study from Madagascar, biomass burning and global change, ed. J. S. Levine. London, England, MIT Press, 1, 73-85.

Hansen, A. D. A., Artz, R. S., Pszenny, A. A. P. and Larson, R. E. 1990. Aerosol black carbon and radon as tracers for air mass origin over the north Atlantic Ocean. Global Biogeochemical Cycles 4, 2, 189-199.

Hao, W. M. and Liu, H. 1994. Spatial and temporal

Tellus 53B (2001), 5 
distribution of tropical biomass burning. Global Biogeochemical Cycles 8, 495-503.

Hao, W. M., Ward, D. E., Olbu, G. and Baker, S. P. 1996. Emissions of $\mathrm{CO}_{2}, \mathrm{CO}$ and hydrocarbons from fires in diverse African savanna ecosystems. J. Geophys. Res. 101, 23,577-23,584.

Hastenrath, S. 1991 (ed). Climate dynamics of the tropics. Updated from Climate and circulation of the tropics. Kluwer Academic Publishers, London.

Hauglustaine, D. A., Ridley, B. A., Solomon, S., Hess, P. G. and Madronich, S. 1996. $\mathrm{HNO}_{3} / \mathrm{NO}_{x}$ ratio in the remote troposphere during MLOPEX 2: evidence for nitric acid reduction on carbonaceous aerosols? Geophys. Res. Lett. 23, 19, 2609-2612.

Hauglustaine, D. A., Madronich, S., Ridley, Flocke, S. J., Cantrell, C. A., Shetter, R. E., Tanner, D. J., Ginoux, P. and Atlas, E. L. 1999. Photochemistry and budget of ozone during the Mauna Loa Observatory Photochemistry Experiment (MLOPEX 2). J. Geophys. Res. 104, 23, 30,275-30,307.

JGR special issue 1996. TRACE-A and SAFARI. Eds. M. O. Andreae, J. Fishman and J. Lindesay. J. Geophys. Res. 101, 000-000.

Johnson, J. E., Gammon, R. H., Larsen, J., Bates, T. B. Oltmans, S. J. and Farmer, J. C. 1990. Ozone in the marine boundary layer over the Pacific and Indian Oceans: latitudinal gradients and diurnal cycles. J. Geophys. Res. 95, 11,847-11,856.

Johnson, J. E. and Isaksen, I. S. A. 1993. Tropospheric ozone chemistry. The impact of cloud chemistry. J. Atmos. Chem. 16, 99-122.

Kalberer, M., Tabor, K., Ammann, M., Parrat, Y., Weingartner, E., Piguet, D., Rössler, E. D., Jost, D. T. Türler, A., Gäggeler, H. W. and Baltensperger, U. 1996. Heterogeneous chemical processing of ${ }^{13} \mathrm{NO}_{2}$ by monodisperse carbon aerosols at very low concentrations. J. Phys. Chem. 100, 15,487-15,493.

Klein, D. 1990. Réalisation et applications d'un compteur proportionnel pour des mesures de terrain en continu $d u$ Radon-222. Thesis. University of Franche-Comté, Physical Chemistry.

Koffi, B., Grégoire, J.-M. and Douglas Eva, H. 1996. Satellite monitoring of vegetation fires on a multiannual basis at continental scale in Africa. Biomass burning and global change, ed. J. S. Levine. London, England, MIT Press, 1, 225-235.

Krishnamurti, T. N., Sinha, M. C., Kanamitsu, M. Oosterhof, D., Fuelberg, H., Chatefield, R., Jacob, D. J. and Logan, J. 1996. Passive tracer transport relevant to the TRACE A experiment. J. Geophys. Res. 101, 23,889-23,907.

Levine, J. S. 1991. Global biomass burning: atmospheric, climatic and biospheric implications. EOS Trans $A G U$ 71, 37-39.

Levine, J. S., Cofer III, W. R., Cahoon, D. R. and Winstead, E. L. 1995. Biomass burning, a driver for global change. Environ. Sci. and Technol. 29, 120A-125A.

Levine, J. S. 1996. Biomass burning and golbal change.
Remote sensing, modeling and inventory development, and biomass burning in Africa, ed. J. S. Levine, 1.

Liousse, C., Cachier, H. and Jennings, S. G. 1993. Optical and thermal measurements of black carbon aerosol content in different environments: variation of the specific attenuation cross-section, sigma $(\sigma)$. Atmos. Environ. 27A, 1203-12-11.

M. France 2000. Atlas climatique de La Réunion (in French). Bureau d'étude climatologique, Direction Interrégionale de La Réunion.

Miller, J. M., Moody J. L., Harris, J. M. and. Gaudry, A. 1993. A 10-year trajectory flow climatology for Amsterdam island, 1980-1989. Atmos. Environ. 27, 12, 1909-1916.

Naja, M., Lal, S., Venkataramani, S., Modh, K. S. and Chand, D. 1999. Variabilities in $\mathrm{O}_{3}, \mathrm{NO}, \mathrm{CO}$, and $\mathrm{CH}_{4}$ over the Indian Ocean during winter. Current Sci. 76, 931-937.

Ogren, J. A., Groblicki, P. J. and Charlson, R. J. 1984. Measurement of the removal rate of elemental carbon from the atmosphere. Sci. Total Environ. 36, 329-338. Olson, J. R. 1996. A study of the mass transport of enhanced continental ozone in the tropics and its impact over the remote southern Atlantic Ocean. Biomass burning and global change, ed. J. S. Levine, 1, 178-192.

Olson, J. R., Baum, B. A., Cahoon, D. R. and Crawford, J. H. 1999. Frequency and distribution of forest savanna, and crop fires over tropical regions during PEM-Tropics A. J. Geophys. Res. 104, 5865-5876.

Penner, J. 1995. Carbonaceous aerosols influencing atmospheric radiation: black and organic carbon. In: Aerosol forcing of climate, eds. R. J. Charlson and J. Heintzenberg. Wiley \& Sons, Chichester, 91-108.

Penner, J., Eddleman, H. and Novakov, T. 1993. Towards the development of a global inventory for black carbon emissions. Atmos. Environ. 27A, 1277-1295.

Polian, G., Lambert, G., Ardouin, B. and Jegou, A. 1986. Long-range transport of continental radon in subantartic and arctic areas. Tellus 38B, 178-189.

Ramonet, M., Le Roulley, J. C., Bousquet, P. and Monfray, P. 1996. Radon-222 measurements during the Tropoz II campaign and comparison with a global atmospheric transport. J. Atmos. Chem. 23, 107-136.

Randriambelo, T., Baldy, S., Bessafi, M., Petit, M. and Despinoy, M. 1998. An improved detection and characterization of active fires and smoke plumes in southeastern Africa and Madagascar. Int. J. of Remote Sensing 19, 2623-2638.

Randriambelo, T., Baray, J.-L., Baldy, S., Brémaud, P. and Cautenet, S. 1999. A case study of extreme tropospheric ozone contamination in the tropics using in-situ, satellite and meteorological data. Geophys. Res. Lett. 26, 1287-1290.

Randriambelo, T., Baray, J.-L. and Baldy, S. 2000. Effect of biomass burning, convective venting, and transport on tropospheric ozone over the Indian Ocean: Réunion island field observations. J. Geophys. Res. 105, D9, 11,813-11,832. 
Rhoads, K. P., Kelley, P., Dickerson, R. R., Carsey, T. P., Farmer, M., Savoie, D. L., Prospero, J. M. and Crutzen, P. J. 1997. The composition of the troposphere over the Indian Ocean during the monsoonal transition. J. Geophys. Res. 102, 15, 18,981-18,995.

Roumeau, S., Brémaud, P., Riviepe, E., Baldy, S. and Baray, J.-L. 2000. Tropical cirrus clouds: a possible sink for ozone. Geophys. Res. Lett. 27, 2233-2236.

Ruellan, S. and Cachier, H. 2001. Characterisation of fresh particulate vehicular exhausts near a Paris high flow road. Atmos. Environ. 35, 453-468.

Stocks, B. J. and Kauffman, J. B. 1997. Biomass consumption and behaviour of wildland fires in boreal, temperate and tropical ecosystems: parameters necessary to interpret historic fire regimes and future fire scenarios. In: Sediment records of biomass burning and global change, eds. J. S. Clark, H. Cachier, J. G. Goldammer and B. J. Stocks. NATO ASI Series on Global Environmental Change. Springer-Verlag: 51, 169-188.

Stull, R. B. 1988. An introduction to boundary meteorology. Atmospheric Sciences Library, Kluwer Academic Publishers.

Talbot, R. W., Dibb, J. E., Sceuer, E. M., Blake, D. R., Blake, N. J., Gregory, G. L, Sachse, G. W., Bradshaw, J. D., Sandholm, S. T. and Singh, H. B. 1999. Influence of combustion emissions on the distribution of acidic trace gases over the southern Pacific basin during austral springtime. J. Geophys. Res. 104, 5623-5634.

Taupin, F. G., Bessafi, M., Baldy, S. and Brémaud, P. J. 1999. Tropospheric ozone above the southwestern Indian Ocean is strongly linked to dynamical condi- tions prevailing in the tropics. J. Geophys. Res. 104, 8057-8066.

Thompson, A. M., Pickering, K. E., McNamara, D. P., Schoeberl, M. R., Hudson, R. D., Kim, J. H., Browell, E. V., Kirchoff, V. W. J. H. and Nganga, D. 1996. Where did tropospheric ozone over southern Africa and the tropical Atlantic come from in October 1992, Insights from TOMS, GTE TRACE A and SAFARI 1992. J. Geophys. Res. 101, 24,251-24,279.

Thompson, A. M., Tao, W. K., Pickering, K. E., Scala, J. R. and Simpson, J. 1997. Tropical deep convection and ozone formation. Bull. Amer. Meteorol. Soc. 78, 1043-1054.

Tyson, P. D., Garstang, M., Swap, R. J., Browell, E. V., Diab, R. D. and Thompson, A. M. 1996. Transport and vertical structure of ozone and aerosol distributions over southern Africa. Biomass burning and global change, ed. J. S. Levine. London, England, MIT Press, 1, 403-421.

Tyson, P. D. and D'Aberton, P. C. 1998. Transport and recirculation of aerosols off southern Africa - macroscale plume structure. Atmos. Environ. 12, 1511-1524.

Wolff, G. T. and Klimisch, R. L. 1982. Particulate carbon: atmospheric life cycle, ed. G. T. Wolff and R. L. Klimisch. Plenum Press.

Zachariasse, M., Van Velthoven, P. F. J., Smit, H. G. J., Leliveld, J., Mandal, T. K. and Kelder, H. 2000. Influence of stratosphere-troposphere exchange on tropospheric ozone over the tropical Indian Ocean during winter monsoon, J. Geophys. Res. 105, D12, $15,403-15,416$ 